\title{
DOUBLE LEG SPEED HOP AND HALF SQUAT JUMP IMPROVE LEG MUSCLE POWER
}

\author{
Gede Aditya Wiratama ${ }^{*}$, I Nyoman Adiputra ${ }^{2}$, I Made Krisna Dinata ${ }^{2}$, Luh Putu \\ Ratna Sundari ${ }^{2}$, Bagus Komang Satriyasa ${ }^{3}$, I Dewa Ayu Inten Dwi Primayanti ${ }^{2}$ \\ ${ }^{1}$ Department Of Sport Physiology Magister Program, Universitas Udayana, 80234, Denpasar, Indonesia \\ ${ }^{2}$ Physiology Departement, Medical Faculty, Universitas Udayana, 80234, Denpasar, Indonesia \\ ${ }^{3}$ Pharmachology Departement, Medical Faculty, Universitas Udayana, 80234, Denpasar, Indonesia \\ adityawiratama12@gmail.com
}

\begin{abstract}
Leg muscle explosiveness is one of the factors determine the stability of jumping techniques in football. This research aims to prove that the combined training of Double Leg Speed Hop and Half Squat Jump is better than the Hurdle Jump in increasing leg muscle explosive power in male students participating in extracurricular football at SMP Negeri 2 Kuta Utara. This research was true experimental with randomized pre and post-test with control group design. Subjects were 18 male extracurricular football at SMP Negeri 2 Kuta Utara in each group. Treatment Group given training Double Leg Speed Hop and Half Squat Jump and Control Group given Hurdles Training, with frequency of training 3 times a week for 6 weeks. Measurement of leg muscle power using meter board with vertical jump test. The Result in both group obtained mean leg muscle power in Treatment group pre-test 38,49 $\pm 4,658 \mathrm{~cm}$ and post-test $48,17 \pm 4,305 \mathrm{~cm}$. Control Group, pre-test $36,63 \pm 3,953 \mathrm{~cm}$ and post-test $40,79 \pm 4,227 \mathrm{~cm}$. The mean difference test in the increased leg muscle power in treatment group and control group using independent $\mathrm{t}$-tests in the post-test data of the two groups showed that $\mathrm{p}=0.00(\mathrm{p}<0.05)$. Concluded that training of both group had increasing effect and Treatment Group increased leg muscle power more than Control Group. Suggestion in this research, hoped that this result can be an alternative choice of train in increasing the leg muscle explosive power.
\end{abstract}

Keywords: Leg Muscle Explosive Power; Double Leg Speed Hop; Half Squat Jump; Hurdles Jumping; Football

\section{INTRODUCTION}

Football is a sport that is very popular with all levels of society. One aspect that needs to be mastered by a soccer player is technique. This technique is one of several aspects of training that needs to be developed in relation to achievement.

The basic techniques of playing football that must be mastered by every soccer player are kicking, dribbling, stoping, heading, tackling, throw-in, and goal keeping. ${ }^{1}$ The correct movement technique according to the theory is when jumping to take the ball in the air is done with both feet instead of one foot. this is aimed at when the repulsion of the legs really gives the maximum explosive power. ${ }^{2}$

The quality of a jump is determined by the power factor of the leg muscles. Strength and speed greatly affect explosive power because strength and speed affect the physical condition. ${ }^{3}$ When making a jumping motion, if the explosive power of the leg muscles does not produce explosive power, it will affect the result of the jump made when in attacking conditions or passing the ball. In the interests of sports, explosive power is meant by explosive power which consists of two biomotor groups, strength and speed. ${ }^{4}$

Based on the facts in the field, that happened to male students of SMP Negeri 2 North Kuta, according to researchers observations, the ability to jump in football was still lacking. This can be seen when training and competing and defensive and attacking variations are not carried out well. The power of the leg muscles which are still weak when doing the basic technique of heading the ball needs to be improved. Efforts to increase good results in the technique of heading the ball with a jump requires proper training, especially to increase the power of the leg muscles on the ability to jump while heading the ball.

In increasing the explosive power of muscles, there is a plyometric training model. Plyometric training is one of the efforts shown to develop explosive power and reaction speed. ${ }^{4}$ 
Plyometric training has various training models, namely in this study a combination of double leg speed hop and half squat jump training and hurdle jumping training.

The combination of double leg speed hop and half squat jump training aims to train and develop muscle strength and reaction speed performing continuous repetitive movements with body weight resistance. This exercise trains the strength of the lower muscles, the hamstrings, quadriceps, gluteus maximus, biceps femoris, semi tendinosus, semi membranosis, and the lower leg muscles, gastrocnemius and soleus. The target of the exercise is to increase the explosive power component. ${ }^{5}$

Another exercise that increases the explosive power of the leg muscles is hurdle jumping training. Hurdle jumping training aims to build leg strength, concentration, and movement speed required in play football. This hurdles serves as a means of ballast, obstacles, challenges so that players are encouraged to overcome them. The work process "overload" by using this obstacle, training feels tough for players. Skipping training trains leg strength and speed of movement when jumping over the hurdle so that the explosive power of the leg muscles is formed. ${ }^{6}$

\section{METHODS}

A. Research design

The research design used experimental randomized pre and post-test control groups design. ${ }^{7}$ this study, there were two groups selected randomly, where the treatment group was given a combination of double leg speed hop and half squat jump training, while the control group was given hurdle jump training. The study was conducted to determine that the combination of double leg speed hop and half squat jump training was better than hurdle jumping training in increasing the explosive power of the leg muscles of the male soccer extracurricular students at SMP Negeri 2 North Kuta.

Population and sample

Samples were taken using random sampling using the Pocock formula which applied 18 people, the sample in this study was divided into two groups based on the criteria set inclusion and exclusion. The inclusion criteria are Age 14-15 years old, students who are still actively participating in extracurricular programs, available to be a respondent and follow the research to completion. The exclusion criteria are have a history of heart and lung disease, respondents experienced musculoskeletal injuries such as fractures and dislocations, drop out criterion is that students do not participate in training for three times in a row and if during the study the sample changes schools.

Sampling technique

The sampling technique used a simple random technique (simple random). The sample was 36 students divided into two training groups. The treatment group was given a combination of double leg speed hop and half squat jump training and the control group was given hurdle jump training.

B. Material and Procedure

1. Field Bina Raga Dalung North Kuta District, Badung Regency.

2. Informed Consent sheet.

3. Metered board.

4. Calcium carbonate powder.

5. Stature Meter merk general core height measuring instrument.

6. Scales merk SIMC ZT-120 to measure body weight.

7. Obstacles $30 \mathrm{~cm}$

8. Writing tool to record reasearch result before and after intervention

9. Camera to document research activities and laptop to store and process research result

Researchers conducted a literature study from books, journals, theses, the internet and various other references related to research, then coordinated with the Principal of SMP Negeri 2 North Kuta and arranged the necessary documents related to research permits and approval. After obtaining permission to conduct research, the researcher designed the schedule and instruments used in the study. The next procedure, the researcher carried out 
introductions, written and oral explanations, research objectives, respondent rights and research benefits. The samples were selected from a population that had met the inclusion and exclusion criteria, then signed an informed consent form. Samples that have been selected randomly (random sampling) are then divided randomly into two groups, namely the treatment group and the control group, then do a pre-test to determine the value of the vertical jump before being given intervention.

The treatment group was given double leg speed hop and half squat jump training with a training intensity of 10 reps 4 sets, and the control group was given training to jump the hurdle with an intensity of 10 reps 4 sets. When the research was carried out, namely Monday, Wednesday and Friday, from 16.00 to 18.00 WITA. Both groups had a frequency of exercise 3 times a week for 6 weeks. Then do a post-test to find out the vertical jump after being given the intervention. The data collected is then analyzed the data then make conclusions by making a report related to the results of the research that has been done.

C. Assessment

The height of the jump was measured using the test parameters and the measurement of the explosive power of the leg muscles using the vertical jump test. The highest and best jump values are the values that are used "valid". The normal value of vertical jump is starting from less than $12.7 \mathrm{~cm}$ to very good $63.5 \mathrm{~cm} .^{8}$

D. Data Analysis

After all data has been collected, data processing and analysis using SPP 16.0 computer software. ${ }^{9}$

1. Normality test

Based on the results of the data normality test (Shapiro-wilk test) the explosive power of the leg muscles before and after the treatment group and control group training showed the results of the $\mathrm{p}$ value of both groups were above 0.05 or $\mathrm{p}$ was greater than $(\mathrm{p}<0.05)$, that the research data is normally distributed.

2. Homogeneity test

Based on the results of the data homogeneity test using the Levenes Test, it shows that the $\mathrm{p}$ value of the two groups is above 0.05 or $\mathrm{p}$ is greater than $(\mathrm{p}<0.05)$ so that the research data is homogeneous.

3. Hyphotesis test

a. Hypothesis 1 test used paired t-test to determine the mean difference in the effect of giving a combination of double leg speed hop and half squat jump training on the increase in leg muscle explosive power, testing the significance of the data before and after in the treatment group.

b. Hypothesis 2 test used paired t test in knowing the mean difference of the effect of jumping hurdle training on the increase in leg muscle explosive power, to test the significance of the data before and after in the Control Group.

c. Hypothesis 3 test used the independent $t$ test in knowing the difference in the effect of the combination of double leg speed hop and half squat jump training and hurdle jumping training on the increase in leg muscle explosive power, to test the significance of the two groups. 


\section{RESULTS}

a. The characteristics of research subjects

The characteristics of the research subjects included: age, weight, height and body mass index (BMI) before being given training in both groups. Table 1 shows that the characteristics of age, height, weight, and BMI of the two groups before training were not significantly different with the Independent $\mathrm{T}$-Test where the results of the analysis obtained a $\mathrm{p}$ value $>0.05$, each group has the same characteristics.

Table 1. The characteristics of research subjects

\begin{tabular}{lccc}
\hline Subject characteristics & $\begin{array}{c}\text { Treatment group } \\
(\text { mean } \pm \text { sd })\end{array}$ & $\begin{array}{c}\text { Control group } \\
(\text { rerata } \pm \text { sd })\end{array}$ & P \\
\hline Age $(\mathrm{yr})$ & $14,44 \pm 0,51$ & $14,61 \pm 0,50$ & 0,53 \\
Height $(\mathrm{cm})$ & $165,44 \pm 4,96$ & $165,72 \pm 4,52$ & 0,72 \\
Weight $(\mathrm{kg})$ & $54,50 \pm 4,21$ & $54,44 \pm 4,34$ & 0,55 \\
BMI $\left(\mathrm{kg} / \mathrm{m}^{2}\right)$ & $19,38 \pm 1,64$ & $19,38 \pm 2,00$ & 0,27 \\
\hline
\end{tabular}

b. Data normality and homogeneity test

Data before and after training based on the normality and homogeneity test for the two groups can be seen in Table 2.Based on the data normality test (Shapiro-Wilk Test) both groups showed (p> 0.05 ) or $\mathrm{p}$ value greater than 0.05 so that the data is stated to be normally distributed. Based on the data homogeneity test (Levenes Test) the two groups showed ( $p>0.05$ ) data was stated to be homogeneously distributed.

Table 2. Test of normality and homogeneity before and after training

\begin{tabular}{llll}
\hline $\begin{array}{l}\text { Measurement of Muscle } \\
\text { Strength }\end{array}$ & $\begin{array}{l}\text { Normality Test } \\
\text { (SaphiroWilk-Test })\end{array}$ & $\begin{array}{l}\text { Homogeneity Test } \\
\text { (Levene-Test) }\end{array}$ \\
\cline { 2 - 4 } & $\begin{array}{l}\text { Treatment Group } \\
\text { p Value }\end{array}$ & $\begin{array}{l}\text { Control Group } \\
\text { p Value }\end{array}$ & p Value \\
& 0,580 & 0,367 & 0,314 \\
Initial Test & 0,839 & 0,377 & 0,684 \\
Final Test & & & \\
\hline
\end{tabular}

c. Test of mean differences increase in leg muscle explosive power before and after training

The mean test of the difference before and after the limb muscle explosive power training can be seen in Table 3.Based on the mean test results in the table above shows ( $p>0.05$ ) or $p$ less than 0.05 which proves a significant increase in explosive power leg muscles in both Groups.

Tabel 3. Test of mean differences increase in leg muscle explosive power before and after training

\begin{tabular}{llll}
\hline $\begin{array}{l}\text { Measurement of leg muscle explosive } \\
\text { power }\end{array}$ & $\begin{array}{l}\text { Before } \\
(\text { Mean } \pm \mathrm{SD})\end{array}$ & $\begin{array}{l}\text { After } \\
(\text { Mean } \pm \mathrm{SD})\end{array}$ & $\mathrm{P}$ \\
\hline Treatment group & $38,49 \pm 4,658$ & $48,17 \pm 4,305$ & 0,000 \\
Control group & $36,63 \pm 3,953$ & $40,79 \pm 4,227$ & 0,000 \\
\hline
\end{tabular}

d. The intergroup effect difference test in determining the final result of leg muscle explosive power

The test for different effects of differences between groups in determining the final result of leg muscle explosive power can be seen in Table 4. Based on the mean difference test of the measurement results before training in the Treatment and Control Group, the value $(p<0,05)$ or $p$ is greater than 0,05 showed no significant differences before training. Based on the mean difference test of the measurement results after training in the Treatment Group and the Control Group with $(p>0,05)$ it shows that there is a significant difference after training 
Table 4. The intergroup effect difference test in determining the final result

\begin{tabular}{llll}
\hline $\begin{array}{l}\text { Measurement of leg muscle explosive } \\
\text { power }\end{array}$ & Treatment group & Control group & P \\
\hline Before & $38,49 \pm 4,658$ & $36,63 \pm 3,953$ & 0,206 \\
After & $48,17 \pm 4,305$ & $40,79 \pm 4,227$ & 0,000 \\
\end{tabular}

\section{DISCUSSION}

a. Increased leg muscle explosive power after combined double leg speed hop and half squat jump training

The combination of double leg speed hop and half squat jump training is one form of plyometric training, which is a combination designed to increase leg muscle explosive power. Movements that develop the elements of speed and muscle strength on which the muscles are based on explosive power. ${ }^{5}$ Training using body weight resistance, this requires the speed and strength of the muscles that contract simultaneously when the movement occurs. ${ }^{6}$

Very high muscle contraction is the ability of a strong and fast muscle to contract, so that the explosive power of the leg muscles is influenced by the components of strength and speed, both the speed of nerve stimulation and the velocity of the muscles that occur. ${ }^{10}$ In addition to increasing the biomotor component, there will be an increase in the ability of physiological responses, namely: innervation adaptation, muscle hypertrophy (enlargement), adaptation of muscle endurance cells and cardiovascular adaptation. ${ }^{11}$

The muscle focus on this training includes; muscle gluteals, hamstring muscles, muscle quardriceps, muscle gastrocnemicus, and soleus which causes an increase in leg muscle explosive power and changes in ligaments and tendons due to structured and systematic training. ${ }^{5}$ The strength of the quardriceps and hamstrings helps joint stability as well as performance. ${ }^{11}$

\section{b. Increased leg muscle explosive power after hurdle jump training}

Hurdle jump is an exercise that functions to build leg strength, concentration, and movement speed needed in the game. This training uses the principle of overload training using a hurdle. The physiological mechanisms of the explosive power of the leg muscles due to jumping the wicket are in this jumping motion, the gluteus maximus and minimus muscles, the quardricep extensor muscle group, the anterior tibia and the muscles in the metatarsals are held in position, the flexor muscles relax. In addition, the influence of speed and thrust when doing the start gives a force that causes the subject to change its speed at the starting point to change the direction of movement horizontal to vertical by $45^{\circ} .6$

The movement of hurdle jump at the time of jumping over the hurdle the movement must be carried out in a continuous, smooth and relaxed manner, it must be done not to float too long so that the speed can be maintained. ${ }^{12}$ The increase in the results of this training jump makes the lower leg muscles coordinated when jumping over an obstacle, the frequency set, the length of training which causes an increase in leg muscle explosive power.

c. The ocmbination of double leg speed hop and half squat jump exercises increases the power of leg muscles more than hurdle jump training

The mean results of the increase muscle explosive power of the two groups had a significant result as a result of the training given. Students who are given 6 weeks of training with a frequency of 3 times a week make their bodies adapt to the exercises given and there is a significant improvement. ${ }^{4}$

With regular exercise will have several positive effects on the muscles, even long-term adaptations can occur in the muscle fibers, which allows for a more efficient response to different types of muscle. ${ }^{13}$ From the results of the study states that the combination of double leg speed hop and half squat jump training increases the explosive power of the leg muscles more than jumping hurdles, because treating high intensity can increase the results of the vertical jump test ${ }^{14}$, seen by the combination of double leg speed hop and half squat jump training resistance load from body weight. 
combination of double leg speed hop and half squat jump training that is repeated or the reflex stretch of the muscles involved to produce an explosive reaction quickly and dynamically before the muscles contract again. ${ }^{15}$ The most important factor is the sensor of the muscle spindle in its role before muscle stretch occurs and input by the sensory is connected to muscle stretching to move quickly. ${ }^{16}$ The role of the muscle spindle and the golgi tendon organ is very important in controlling the amount of force applied so that the potential for injury when performing a combination training movement is minimized and results in a better explosive power output. ${ }^{17}$

The combination of double leg speed hop and half squat jump training improves the lower body muscles, namely the hamstrings, quadriceps, gluteus maximus, biceps femoris, semi tendinosus, semi membranosis, and lower leg muscles, gastrocnemius and soleus muscles. The aim of the exercise is to increase the explosive power component. ${ }^{5}$

The results of the combination of exercise from physiological factors show an increase in the strength of innervation adaptation, hypertrophy (enlargement) of muscle cell adaptation, muscle endurance and cardiovascular adaptation. This can be seen from the training mechanism that uses the adaptation of two movement methods that are almost the same but have a burden from the body. The effect generated more by the combination of double leg speed hop and half squat jump training is greater than that of hurdle jumping training.

The combination of double leg speed hop and half squat jump training is a dominant exercise using an anaerobic system which has a special characteristic, namely very strong muscle contraction in jumping and holding body weight. This increase has a positive effect on the ability of the muscles to respond to the stimuli provided so that strength and speed unite and produce maximum leg muscle explosive power.

In this reaserch, the combination of double leg speed hop training and half squat jump training to jump the hurdle with 6 weeks of training with a frequency of 3 exercises can improve balance. Judging from the combination method of double leg speed hop and half squat jump training which uses internal weights, while the hurdle jump training uses external weights, namely the obstacle during training. This training difference makes the combination of double leg speed hop and half squat jump training have a greater intensity to train the explosive power of the leg muscles than the hurdle jumping training.

\section{CONCLUSION}

Based on the results of this research, the combination of Double Leg Speed Hop and Half Squat Jump Training and Hurdle Jump Training can increase the leg muscle explosive power of male soccer extracurricular students at SMP Negeri 2 North Kuta. However, the Combined Double Leg Speed Hop and Half Squat Jump training has been shown a higher level of progression in increasing the explosive power of the leg muscles. The results of this research can be used as a reference or alternative in an exercise program related to the explosive power of the leg muscles. For the next researcher, it is necessary to control the nutritional intake of students, so that research can be better.

\section{CONFLICT OF INTEREST}

The authors declare no conflict of interest.

\section{ACKNOWLEDGEMENT}

The author would like to thank the male students of the soccer extracurricular activities at SMP Negeri 2 North Kuta and their coach Mr. I Made Rai Surya Wienata for their assistance and contribution during the implementation of this training. Thanks also to the Sports Physiology Study Program, Faculty of Medicine, Udayana University who has provided motivation and assistance so that this thesis can be completed.

\section{REFERENCES}

1. Kusuma, K.C.A..2019. Kepelatihan Sepak Bola :Teori dan Praktik. Jakarta: PT. Raja GrafindoPersada.

2. Sudjarwo, I. 2015. Permainan Sepak Bola. Tasikmalaya: PJKR FKIP UNSIL.

3. Juliantine, T. 2007. Modul Mata Kuliah Teori Latihan. Bandung: FPOK UPI.

4. Nala, 2015. Prinsip Pelatiahan Fisik Olahraga. Denpasar : Udayana University Press. Cetakan Ke-2.

5. Sukadarwanto \& Utomo, B. 2014. Perbedaan Half Squat Jump dan Knee Tuck Jump Terhadap Peningkatan Daya Ledak Otot dan Kelincahan. Jurnal Terpadu Ilmu Kesehatan, (Online), Vol 3, Nomor 2. 
6. Martina, N. 2013. Pengaruh Latihan Pliometrik menggunakan Skipping dan Lompat Gawang Terhadap Power Otot Tungkai Peserta Ekstrakurikuler Bola Voli di SMP Negeri 7 Pekalongan. Universitas Negeri Yogyakarta.S

7. Sukestiyarno. 2014. Statistik Dasar: Konsep Statistika. Yogyakarta: Andi Publisher.

8. Purba. 2014. Prosedur Pelaksanaan Tes Kondisi Fisik / Tes Fisiologi Atlet. Bandung: PAIFORI.

9. Santoso, S. 2018. Menguasai Statistik Dengan SPSS. Jakarta: PT. Elex Media Komputindo.

10. Dewi. K.L.P., Adnyana, N.L.N., Dinata, I.M.K. 2016. Intervensi Integrated Neorumuscular Inhibition Technique (Init) dan Infrared Lebih Baik Dalam Menurunkan Nyeri Myofaccial Pain Syndrome Otot Upper Trapezius Dibandingkan Intervensi Myofasial Release Technique dan Infrared pada Mahasiswa Fisioterapi. Majalah Ilmiah Fisioterapi Indonesia. Vol 2 (1).

11. Emral.2018. Pengantar Teori \& Metodologi Pelatihan Fisik. Depok: Kencana.

12. Furqon. H. 2012. Pliometrik Untuk Meningkatkan Power. Surakarta: Program Pasca Sarjana Universitas Sebelas Maret.

13. Amin, M. 2014. Pengaruh Lantihan Loncat Gawang Terhadap Peningkatan Daya Ledak Otot Tungkai Pada Atlet Bulu Tangkis Klub PB Citra Kecamatan Agramakmur Kabupaten Bengkulu Utara.

14. Wiarto, G. 2013. Fisiologi dan Olahraga. Yogyakarta: Graha Ilmu.

15. Vanci, M. 2013. Short Term High Intensity Training Program Improves Strengh, Power, and Agility in Male Soccern Players.

16. Lubis, J. 2009. Mengenal Latihan Pliometrik. Online. Avaible from: http://google.com/archive/Mengenal_Latihan_Pliometrik.pdf.

17. Donald A. Chu, Ph.D. 2015. Plyometrics for Youth. Avaible from: http//www.donchu.com/articles/article7/. 